Vol. 39(1), pp. 72-91, June 2020

ISSN 1821-536X (print)

ISSN 2619-8789 (electronic)
Tanzania Journal of Engineering and Technology

Copyright (C) 2020 College of Engineering and

Technology, University of Dar es Salaam

Full Length Research Paper

\title{
Spatial and Temporal Variation of Rainfall and Streamflow in the Kikuletwa Catchment of Upper Pangani Basin, Tanzania
}

\author{
Upendo E. Msovu ${ }^{1}$, Deogratius M.M. Mulungu ${ }^{1}$, Joel K. Nobert ${ }^{1}$, Patrick Valimba ${ }^{1}$ and \\ Henry Mahoo
}

${ }^{1}$ Department of Water Resources Engineering, University of Dar es Salaam, Tanzania

${ }^{2}$ Department of Agricultural Engineering, Sokoine University of Agriculture, Tanzania

Corresponding author: upendoeliuze@yahoo.co.uk

\begin{abstract}
Streamflow and rainfall records from 1980 to 2015 as a (common period for the analyzed stations) were used to analyze the variations of rainfall and streamflow in the Kikuletwa catchment. Also, the analysis of the longest time series available at each station up to 2015 (referred to as the whole series in this study) was conducted to relate past rainfall and streamflow changes, at the tributaries of Kikuletwa River located above the Rundugai natural springs as recommended from previous studies. Various methods such as simple statistics of the mean, standard deviation, coefficient of variance, and graphs were used to analyze intra-annual variations. Multi-year variability was analyzed by trends and change point tests using MannKendall and Pettitt tests respectively. The results of the study revealed the spatial variation of rainfall which was related to elevation differences. The streamflow amounts were found to vary from upstream to downstream. The whole time series analysis of annual rainfall and streamflow amounts revealed a decrease in rainfall and streamflow amounts for almost all stations though a significant decrease was only observed at two stations located on the upstream (for rainfall) and two stations located above the Rundugai natural springs (for streamflow). During 1980 - 2015, trends analysis indicated significant decreasing trends only in annual rainfall amounts at the two stations located on the upstream of the catchment with $Z$ values of -3.20 and -2.68. In contrast, average annual flow trends analysis indicated significant decreasing trends at four stations out of five with $Z$ values of $-2.52,-2.28$, -1.99 and -3.4 and, at one station insignificant decreasing trend was observed. The findings revealed the existence of other catchment influences to the streamflow changes other than rainfall during 1980-2015. The study provides very useful information that decides the necessity for separating the climate and human influences to the streamflow changes to find the most influencing factor.
\end{abstract}

Keywords: Variation, Rainfall, streamflow, Mann- Kendall, Pettit test, Kikuletwa catchment 


\section{INTRODUCTION}

Streamflow and rainfall variations have been reported in various places all over the world (Valimba, 2008; Petrone et al., 2010; Zhang et al., 2014; Langat et al., 2017; Otte et al., 2017). The causes of streamflow variations are believed to be the changes in climate variables, water resources project undertakings, diversions from the rivers for various water uses (withdrawals), and changes in anthropogenic (human) activities that result in land use/cover change (LULCC). The consequences of all these, are the changes in the hydrology of the catchment (Zheng et al., 2009; Xu et al., 2010). These kinds of variations or changes in the flow regime which resulted from natural or man-made changes to the environment can be verified by the recorded data series of the flow regime to be non-homogeneous. The report by the Intergovernmental Panel for Climate Change (IPCC) (2014) predicted that precipitation amount is expected to increase in some areas and decrease in others. Thus, floods, drought, and water scarcity are likely to vary in some seasons or areas and the results of these variations are the threat in water resources.

Variations and pattern analysis are important as historical records of climate variables and streamflow have the potential to be used as a basis for water resource planning and management strategies. Trend analysis is important in highlighting the direction of change while change point analysis detects the presence of an abrupt change in the mean of time series data when the exact time of change is unknown, link events, and suggesting the causes (Valimba, 2008). Shifts in climate patterns and hydrological regimes have an influence on water resources in various uses such as in irrigated agriculture, domestic water supply, industrial water use, and hydropower production (Langat et al., 2017). To do such analysis, representative hydroclimatological stations of reasonably long time series and with few missing data or minimal gaps are selected. WMO (2000); Kundzewicz and Robson (2004) recommend the use of long term periods of data of at least 30 years and above to ensure statistical validity of results and this was also one of the selection criteria for the stations used in this study.

In Tanzania, streamflow variations are highly prevalent in much of the watersheds. Kikuletwa catchment is found in the Pangani River basin which is already referred to as a "closed basin" (Grossman, 2008) as there is no longer enough water to meet both social and environmental needs since demand exceeds the amount of water available. Individual studies (e.g. Mkhandi and Ngana, 1999; Chan et al., 2008; Valimba, 2008; Otte et al., 2017) on temporal and spatial variations on rainfall and streamflow have been conducted in Kikuletwa catchment and Pangani basin as a whole. However, these studies have some limitations and this study identified three gaps to be filled: (1) the period of study. Most of the data used in the previous were up to the 1980s and 1990s. With increased population and climate change, streamflow might have been changed, (2) the comparison between the changes of rainfall to streamflow changes is poorly understood, (3) studies did not consider the tributaries for the main Rivers. Also, the relationship between past rainfall and flow during low flow seasons at the tributaries located above the Rundugai natural springs were not well known compared to the stations located below the Rundugai springs.

This study, therefore, aims at analyzing the spatial and temporal variation of rainfall and streamflow in the Kikuletwa catchment, in Northern Tanzania. Specifically, the study analyzes rainfall and streamflow seasonality, spatial 
variation in rainfall and streamflow, and temporal variations whereby seasonality changes, trends, and change-point analysis in streamflow and rainfall variables were done.

\section{METHODS AND MATERIALS}

\section{The Study Area}

The Kikuletwa catchment with an area of about $6657 \mathrm{~km}^{2}$, lies between latitudes $3^{\circ} 00^{\prime}$ and $3^{\circ} 30^{\prime}$ ' South and between longitudes $36^{\circ} 30^{\prime}$ and $37^{\circ} 15^{\prime}$ ' East. It is located in the north-western part of the Pangani River basin found in the Northeast of Tanzania (Figure 1). Kikuletwa catchment has three major springs (Chemka, Rundugai, and Kware) which contribute about $90 \%$ of the dry season low flow downstream in the Kikuletwa catchment (Rohr and Killingtveit (2002). Also, the catchment has fifteen major rivers which are: Ngaramtoni, Themi, Usa, Ngarasero, Tengeru, Magdarisho, Malala,
Nduruma, Maji ya Chai, Kware, Longoi, Sanya, Karanga, Weruweru and Kikafu which rise on the slopes of Mount Meru and the southern slopes of Mount Kilimanjaro (PBWO/IUCN, 2008). The water users include small-scale subsistence farmers, two cities (Arusha and Moshi), large-scale export/commercial farms, pastoralists, miners, and tourist facilities. The altitude rises from $670 \mathrm{~m}$ to $5,895 \mathrm{~m}$ whereby the Mount Kilimanjaro summit (Kibo) is the highest point and the lowest point is found in Kikuletwa catchment at the outlet of Kikuletwa River to the Nyumba ya Mungu Reservoir. The long rainfall season (Masika) starts from midMarch to the end of May, while the short rainfall season (Vuli) starts from midOctober to the end of December. The highest rainfall which varies from 1000 to $2500 \mathrm{~mm} /$ year, appears in the highlands, southern mountain slopes of Mount Kilimanjaro and Meru. In the lowlands, annual rainfall is commonly between 300 to $600 \mathrm{~mm} /$ year (PBWO/IUCN, 2008).

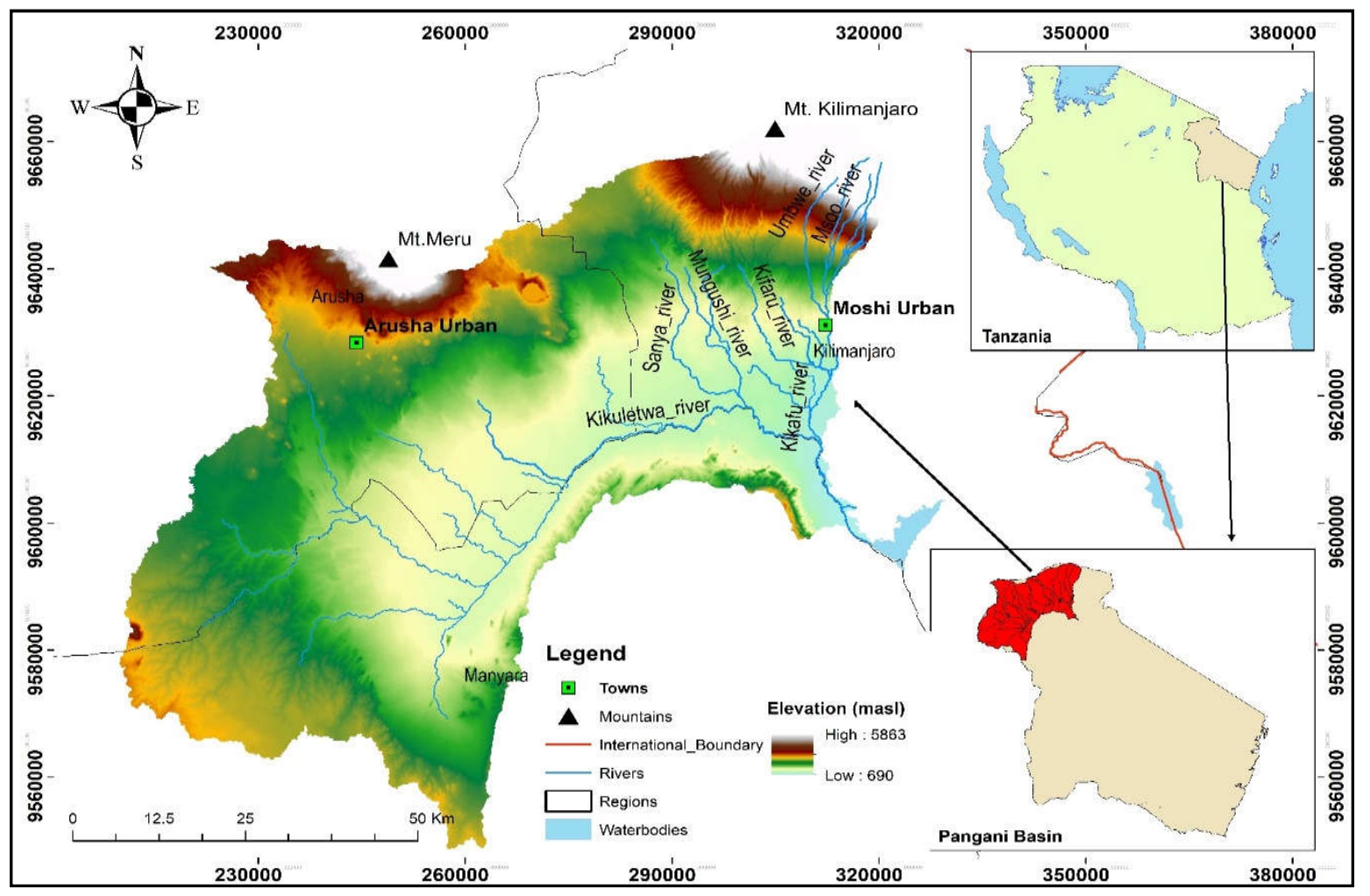

Figure 1: The Kikuletwa catchment and its location in the Pangani basin 


\section{Analysis of Data}

Climatic data (rainfall) at a daily time-step used in this study were obtained from the Ministry of Water Tanzania, Pangani Basin Water Board at Moshi, Tanzania Meteorological Agency (TMA) and the Department of Water Resources Engineering of the University of Dar es Salaam (UDSM). The period of interest of data for this study as a common period for all stations was 1980-2015. However, analysis of the all records available in each station up to 2015 (referred to as the whole series in this study) was also conducted to relate past rainfall and streamflow changes, especially for low flow season at the tributaries located above the Rundugai natural springs, as recommended by Munishi et al. (2009). Quality assessment of data was conducted to test for normality, homogeneity, and outliers. The selection of stations was based on data quality, common period, and spatial distribution. Tables 1 and 2 show the rainfall and streamflow inventory used in this study.

Table 1: Inventory of selected climate records and the availability of daily data

\begin{tabular}{|l|l|l|c|c|c|}
\hline S/N & $\begin{array}{l}\text { Station } \\
\text { Code }\end{array}$ & Station Name & Latitude & Longitude & $\begin{array}{l}\text { Available } \\
\text { Records }\end{array}$ \\
\hline 1 & 09336000 & Olomotonyi & -3.3 & 36.65 & $1956-2015$ \\
\hline 2 & 09336001 & Arusha coffee & -3.38 & 36.68 & $1956-2015$ \\
\hline 3 & 09336014 & Monduli & -3.32 & 36.45 & $1956-2015$ \\
\hline 4 & 09336033 & Arusha airport & -3.37 & 36.63 & $1960-2015$ \\
\hline 5 & 09336035 & Tengeru estate & -3.38 & 36.87 & $1980-2010$ \\
\hline 6 & 09337004 & Moshi airport & -3.35 & 37.33 & $1956-2015$ \\
\hline 7 & 09337028 & TPC Langasani & -3.53 & 37.33 & $1956-2011$ \\
\hline 8 & 09337091 & WD\&ID Moshi maji & -3.34 & 37.34 & $1956-2015$ \\
\hline 9 & 09337021 & Lyamungo & -3.233 & 37.25 & $1956-2015$ \\
\hline 10 & 09337115 & Kilimanjaro airport (KIA) & -3.42 & 37.07 & $1972-2015$ \\
\hline
\end{tabular}

Table 2: Inventory of streamflow data selected and record availability

\begin{tabular}{|c|l|l|l|l|l|}
\hline $\mathbf{S} / \mathbf{N}$ & $\begin{array}{l}\text { Station } \\
\text { code }\end{array}$ & Station Name & Latitude & Longitude & $\begin{array}{l}\text { Available } \\
\text { record }\end{array}$ \\
\hline 1 & IDD1 & Kikuletwa at TPC & -3.53 & 37.33 & $1952-2015$ \\
\hline 2 & IDD54 & Kikuletwa at Power station & -3.46 & 37.29 & $1967-2015$ \\
\hline 3 & IDD55 & Kikuletwa at Karangai & -3.44 & 36.86 & $1976-2015$ \\
\hline 4 & IDD8A & Kikafu & -3.33 & 37.23 & $1980-2015$ \\
\hline 5 & IDD20A & Nduruma & -3.38 & 36.76 & $1980-2015$ \\
\hline 6 & IDD6A & Weruweru at forest & -3.37 & 36.87 & $1959-2004$ \\
\hline 7 & IDE6 & Themi & -3.38 & 36.86 & $1960-2006$ \\
\hline
\end{tabular}

\section{Methodology}

Various methods such as simple statistics of the mean, standard deviation, coefficient of variance, and graphs were used for the spatial and temporal variation analysis.
Trend analysis in rainfall and streamflow data

Mann (1945) and Kendall (1975) test was used for detecting the presence or absence of trends in time series data. It is a nonparametric (distribution-free) rank- 
based test. The test is capable of dealing with outliers and missing data. If the sequence of data $\mathrm{x}_{1}, \mathrm{x}_{2}, \ldots . . \mathrm{x}_{\mathrm{n}}$ exists, the test compares $x_{i}, i=1,2, \ldots(n-1)$ with all subsequent values. When $x_{i}$ tends to be smaller or larger than $\mathrm{x}_{\mathrm{i}+1}, \mathrm{x}_{\mathrm{i}+2}, \ldots . \mathrm{x}_{\mathrm{n}}$, there is an increasing or decreasing trend respectively. Mann-Kendall statistic $\mathrm{S}$ is given as shown by equation (1).

$$
S=\sum_{i=1}^{n-1} \sum_{j=i+1}^{n} \operatorname{sgn}\left(x_{j}-x_{i}\right)
$$

Where $\mathrm{S}$ is defined as total sgn (sign) of the whole time series, sgn is defined as shown by equation (2).

$$
\operatorname{sgn}\left(x_{j}-x_{i}\right)=\left\{\begin{array}{c}
1 \text { if } x_{j}>x_{i} \\
0 \text { if } x_{j}=x_{i} \\
-1 \text { if } x_{j}<x_{i}
\end{array}\right.
$$

and is used to count the difference between two values $x_{i}$ and $x_{j}$ which are the sequential data values and $\mathrm{n}$ is the total number of the recorded data in the time series. The Mann Kendall statistic test Sstatistic and its variance $\operatorname{Var}(S)$ were used to calculate a standard normal variate $Z$, at the $95 \%$ confidence level $(|Z|>1.96)$. The $\mathrm{Z}$ value is used in assessing whether the trend is significant or not significant.

\section{Change point analysis in hydrological and meteorological data}

Change-point analysis in streamflow and rainfall data was conducted to detect the presence of an abrupt change point in the mean of time series data when the exact time of change is unknown. For this study, the Pettitt test (Pettitt, 1979) (nonparametric rank-based test) was used. Once the change point is detected through the test, the dataset is divided into two intervals before and after the change point to form homogeneous groups, which take heterogeneous characteristics from each other. For a time, series X(n), the separated two sub-samples before and after the date $\tau$, Pettitt statistics $\mathrm{k}(\tau)$ can be computed as follows:

$$
k(\tau)=\sum_{i=1}^{\tau} \sum_{j=\tau+1}^{n} \operatorname{sgn}\left(x_{j}-x_{i}\right)
$$

The most significant change point occurs at the date $\tau$ where the absolute value of $\mathrm{k}$ $(\tau)$ reaches the maximum. A significant abrupt change point was decided using the t-test.

\section{Intra-annual (within the year) variations}

Intra-annual variation was analyzed using the long term mean monthly rainfall and flow.

\section{Multi-year variability}

Seasonality change was analyzed using 5 years' monthly averages to find out if there were any notable changes in flow peak or rainfall amounts. Changes in normal rainfall and flow were analyzed using trends and change-point analysis of seasonal and annual rainfall and flow. Changes in flow extremes were analyzed by trends and change-point analysis for high and low flow indices. For high flow indices, maximum discharge for annual, April, and May months (denoted as Annual_QMax., April_Qmax., and May_Qmax) and Q5 were used. For low flow indices minimum discharge for annual, February, and March months (denoted as Annual_QMin., Feb_QMin., and March_QMin.), Q70, and Q95 were used. The high and low flow indices were adopted from the study by Valimba (2004).

\section{RESULTS}

\section{Rainfall Seasonality and Intra-annual (within the year) Variations}

The results of the long term mean monthly precipitation (MMP) and mean annual precipitation (MAP) amounts are shown in Figure 2. The observations from Figure 2 demonstrates bimodal rainfall characteristics in the catchment. This type of rainfall regime has two rain seasons (i.e. 
long rain seasons from mid- March to May (MAM) and short rains from mid-October to December (OND) and sometimes January. These seasons are the result of seasonal migration of the intertropical convergence zone (ITCZ) (Valimba, 2004;
Mutai and Ward, 2000; Camberlin and Philippon, 2002). June, July, August, and September (JJAS) are dry months. The area experiences less or unordinary rain during January -February (FB).

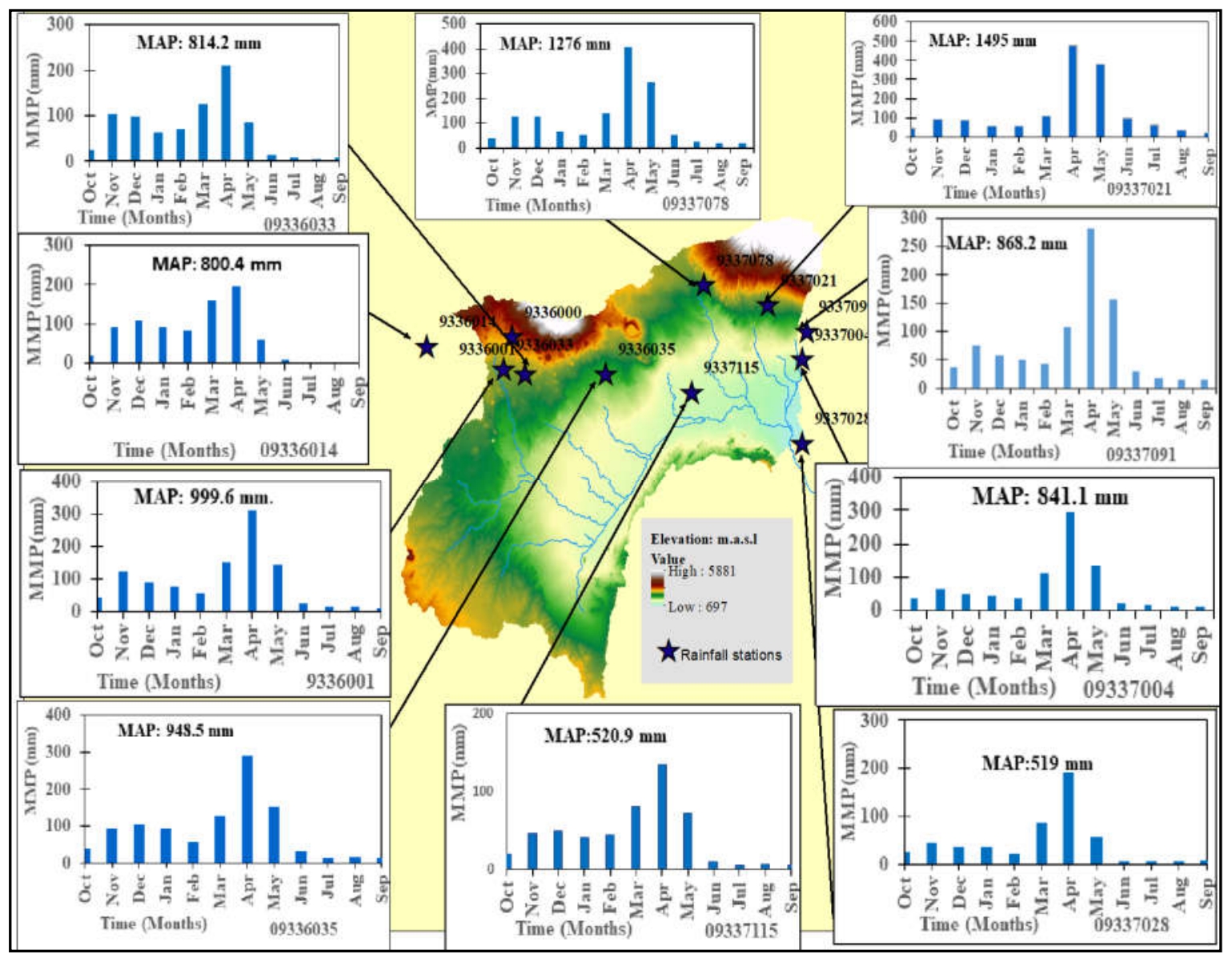

Figure 2: Rainfall Seasonality and Spatial Variation in Mean Monthly Rainfall

Furthermore, the plots of mean monthly precipitation (MMP) and mean annual precipitation (MAP) amounts in Figure 2 demonstrates variations from place to place. For example, MAP at station 09337021 and station 09337078 in the highland is about $1495 \mathrm{~mm}$ and $1276 \mathrm{~mm}$, respectively. The MAP decreases to about $814.2 \mathrm{~mm}$ when moving downward from the highlands, for example, station 09336033. The wide range of topographic differences in the catchment leads to the rainfall differences. The lowlands receive less rainfall to about $519 \mathrm{~mm}$ for example station 09337028 at TPC. Highlands areas receive more rainfall than the areas in the middle and lowland. The coefficient of variation (not shown here) for MAP for each station varies from $22.6 \%$ to $64.7 \%$.

Also, seasonal rainfall distribution, in the same location (station code) showed temporal variations as presented in Figure 3 for station 09336000 . The observations from Figure 3 show that in some period short rain seasons have higher rainfall amounts than the long rain season for example 3(a) for the year 1984/1985 (hydrological year) while in others, short rain season may be missing for example 3(c) for the year 1996/1995. In some years, 
the long rain season has more rainfall (which is normal in the study area) than short rains for example 3(b) for the year $1956 / 1957$ while in others short rain season is almost equal to the long rain season for example 3(d) for year 1992/1993.

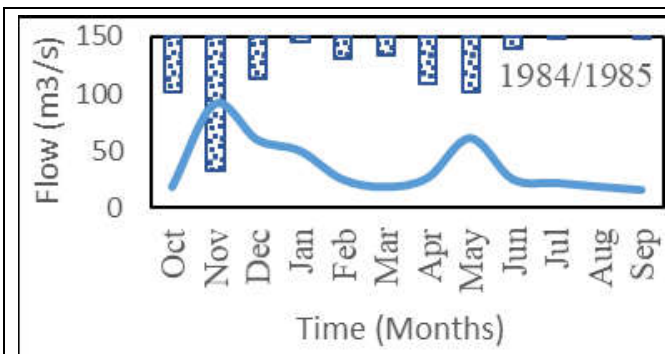

Fand Monthly rainfall $=$ Monthly Flow

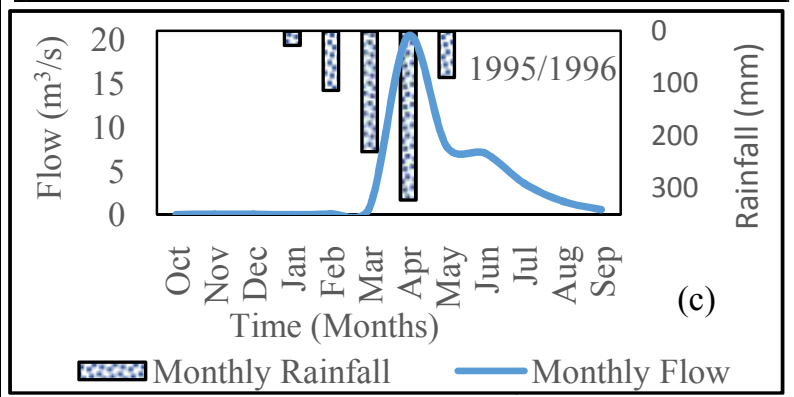

(a)
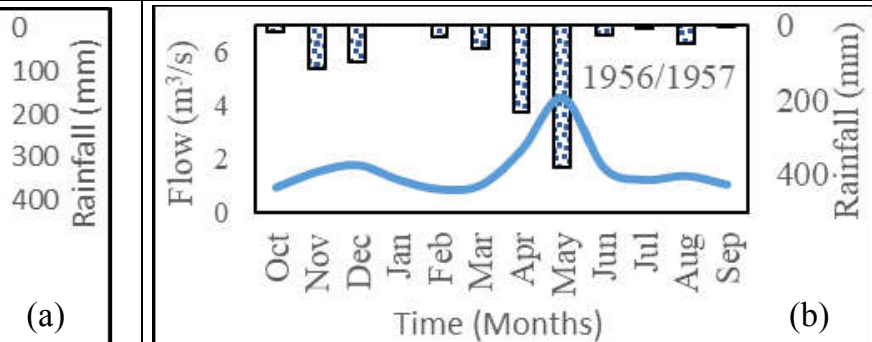

Henth Month rainfall

Monthly flow

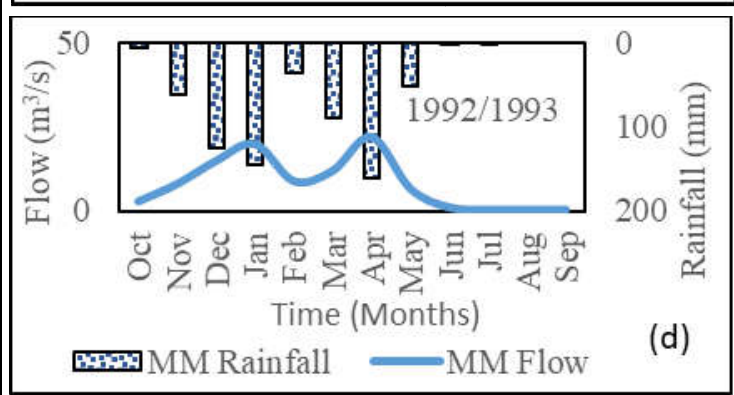

\section{Figure 3: Temporal Variation of Mean Monthly Rainfall Pattern at Station 09336000}

\section{Rainfall Seasonality Change}

The results of seasonality changes are presented in Figure 4, which shows variations of rainfall amounts over the years. However, no shifting of rainfall seasons was noticed. The past periods, for example, the 1960s and 1970s found to have high rainfall and these results are similar to the previous study by Valimba (2004). The decrease in rainfall amounts was noticed from the 1980s. The decrease in rainfall was also revealed by other studies (e.g. Mkhandi and Ngana, 1999). After the 1970s high rainfall, most of the rise in rainfall amounts were related to extreme events, for example, the 1979 floods, 1982, and 1997 El Niño as revealed from previous studies (e.g. Nyezi et al., 1999).

\section{Trends of Seasonal and Annual Rainfall}

The results of annual and seasonal rainfall amount trend analysis for both series (whole and common period) with MK statistic test $Z$ values at the $95 \%$ confidence level $(|Z|>1.96)$ and significant trends in bold are presented in Table 3. Trends analysis of annual rainfall amounts for the whole and common period indicated decreasing trends but significant trends were observed only at stations 09336000 and 09336001 with $Z$ values 2.55 and -3.22 , respectively for the whole series while $Z$ values for the common period were -3.20 and 2.68, respectively. For seasonal analysis, the MAM season indicated decreasing trends for both for the whole and common series but only one station indicated significant decreasing trends in each time series. The OND season indicated an insignificant 
increasing trend for the whole series for seven stations out of ten while the common period indicated insignificant decreasing trends for seven stations out of eight.

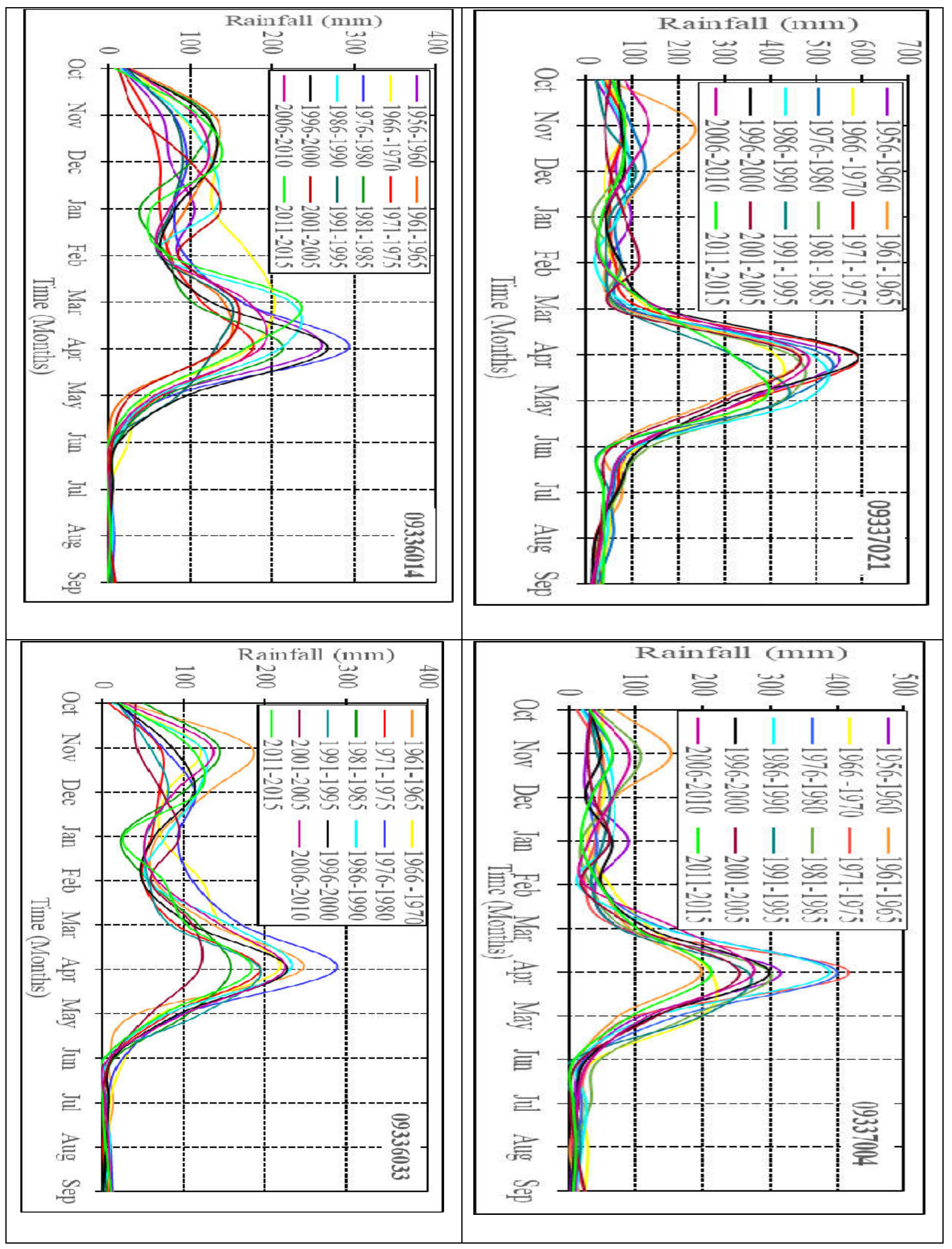

Figure 4: Changing of Rainfall Seasonality in Kikuletwa Catchment of Pangani Basin 
Table 3: Mann-Kendall statistic $Z$ value for seasonal and annual precipitation

\begin{tabular}{|c|c|c|c|c|c|c|c|c|c|c|c|c|}
\hline \multirow{2}{*}{$\begin{array}{l}\mathbf{S} / \\
\mathbf{N}\end{array}$} & \multirow{2}{*}{$\begin{array}{l}\text { Station } \\
\text { code }\end{array}$} & \multirow{2}{*}{$\begin{array}{l}\text { Available } \\
\text { data }\end{array}$} & \multicolumn{5}{|c|}{ Trend in entire (whole) period } & \multicolumn{5}{|c|}{ Trend in common period $(1980-2015)$} \\
\hline & & & Annual & $\mathbf{J F}$ & MAM & JJAS & OND & Annual & $\mathbf{J F}$ & MAM & JJAS & $\overline{\text { OND }}$ \\
\hline 1 & 09336000 & $1956-2015$ & -2.55 & -1.25 & -2.56 & -1.62 & -1.95 & -3.20 & -0.97 & -1.54 & -0.99 & -2.76 \\
\hline 2 & 09336001 & $1956-2015$ & -3.22 & -2.10 & -1.92 & -1.29 & -0.99 & -2.68 & -0.14 & -2.29 & -0.04 & -0.53 \\
\hline 3 & 09336014 & $1956-2015$ & -0.99 & -1.08 & -0.69 & -1.75 & 1.12 & -0.77 & -0.06 & -1.23 & -3.10 & 0.16 \\
\hline 4 & 09336033 & $1960-2015$ & -1.63 & -1.00 & -0.69 & -2.41 & 0.14 & -0.67 & 0.80 & -0.20 & -1.33 & -0.27 \\
\hline 5 & 09336035 & $1980-2010$ & 0.17 & 0.63 & -0.96 & -0.21 & 0.57 & & & & & \\
\hline 6 & 09337004 & $1956-2015$ & -0.96 & -2.06 & 0.03 & -1.17 & 0.18 & -1.78 & 0.23 & -1.59 & -1.81 & -0.86 \\
\hline 7 & 09337021 & $1956-2015$ & -1.58 & -1.71 & -0.49 & -2.25 & 0.47 & -1.21 & -0.19 & -1.10 & -1.40 & -0.42 \\
\hline 8 & 09337028 & 1956-2011 & 0.10 & -1.52 & 0.07 & -0.24 & 0.24 & & & & & \\
\hline 9 & 09337091 & $1956-2015$ & -1.49 & -1.69 & $\begin{array}{l}-0.61 \\
\end{array}$ & -2.02 & -1.21 & -1.93 & -0.64 & -1.73 & -2.43 & -1.67 \\
\hline 10 & 09337115 & $1972-2015$ & -0.36 & -0.37 & 0.04 & -1.85 & 0.65 & -0.53 & 0.50 & -0.05 & -1.73 & -0.63 \\
\hline & \multicolumn{2}{|l|}{ Summary } & & & & & & & & & & \\
\hline & \multicolumn{2}{|c|}{ Number of stations used } & 10 & 10 & 10 & 10 & 10 & 8 & 8 & 8 & 8 & 8 \\
\hline & \multicolumn{2}{|c|}{ Increasing trends stations } & 2 & 1 & 3 & 0 & 7 & 0 & 3 & 0 & 0 & 1 \\
\hline & \multicolumn{2}{|c|}{ Decreasing trends stations } & 8 & 9 & 7 & 10 & 3 & 8 & 5 & 8 & 8 & 7 \\
\hline
\end{tabular}

\section{Change point analysis of seasonal and annual rainfall amounts}

Annual rainfall amount for the common period indicated a significant downward shift at stations 09336000 and 09336001 which occurred in 1997 and 2002 with $\mathrm{t}$ values of 4.4 and 3.6 respectively. Similarly, the whole series indicated a significant downward shift for the annual rainfall amounts to the same stations. On the other hand, the MAM season indicated a significant downward abrupt change at station 9336033 for the whole and common period in 1997 with $t$ values of 4.0 and 2.9 for the whole and common period series, respectively. The OND season indicated a significant downward shift only at station 09336000 in 1992 with a t value of 3 during 1980-2015.

\section{Variation of streamflow in Kikuletwa catchment}

\section{Streamflow seasonality and intra-annual variations}

The analysis of the long term monthly average flow is presented in Figure 5. It shows bimodal flow distribution which reflects the rainfall seasons in the study area. As a result, the catchment has four flow seasons which are: Medium flow season which include the months November, December and January (NDJ) resulting from the short rain season, the high flow season including months April, May, and June (AMJ) resulting from high rain season, the low flow season which includes months February and March (FM) which starts after short rain season and the dry season low flow season which starts after long rain season with months July, August, September, and October (JASO. Further observations from Figure 5 show that flow peaks at highlands during short rain season are higher compared to lowlands as observed in IDD8A and IDD6A. According to Gray (1970), the shape of the hydrograph is affected by both climatic and the biophysical characteristics of the watershed whereby, climatic factors control the rising limb while watershed characteristics, recession limb. The higher the rainfall intensity and duration the higher the flow peaks and stormflow volume. Kikuletwa catchment experiences more rainfall at the highlands than the lowlands. This could be one of the reasons why the peaks of flow hydrograph during short rain are higher at the mountain than at the lowlands. Furthermore, some of the flow peaks during the short rain season at the lowlands are missing (e.g. IDE6) and this could be due missing of the rain season, over-abstraction/withdrawals for irrigation while in others peaks are broader and short (e.g. IDD1) and this could be due to the presence of wetlands floodplain in these 
areas where the flow is stored in the floodplain alluvium which later is released to the channel through the base flow.

Also, at the downstream of the catchment flow amount is higher than that of upstream (Figure 6). One reason could be due to the presence of Rundugai natural springs. Apart from the Rundugai natural springs, it can also be due to intervening streams during the main River.

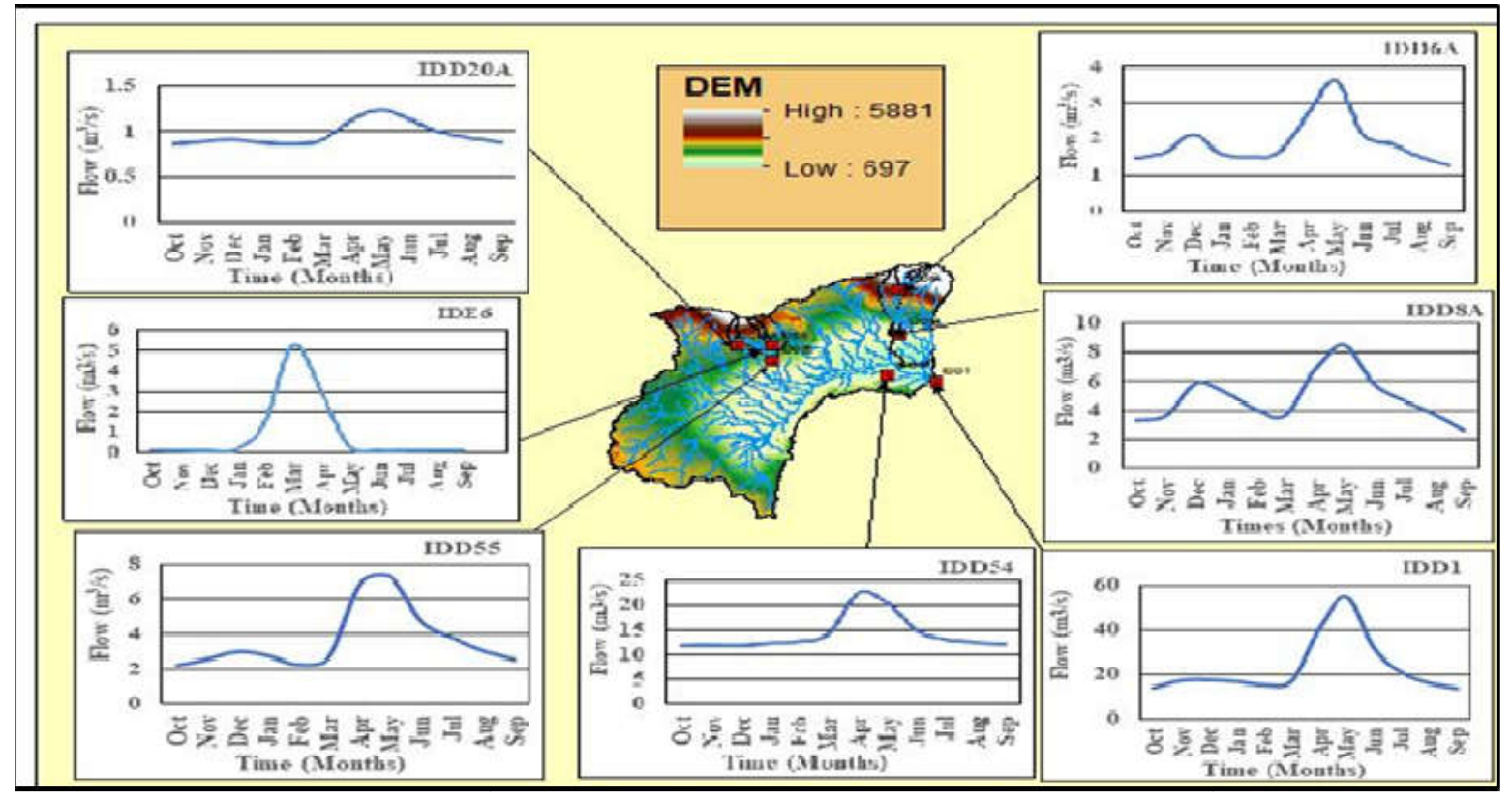

Figure 5: Flow Seasonality and Spatial Variation of Streamflow in the Catchment

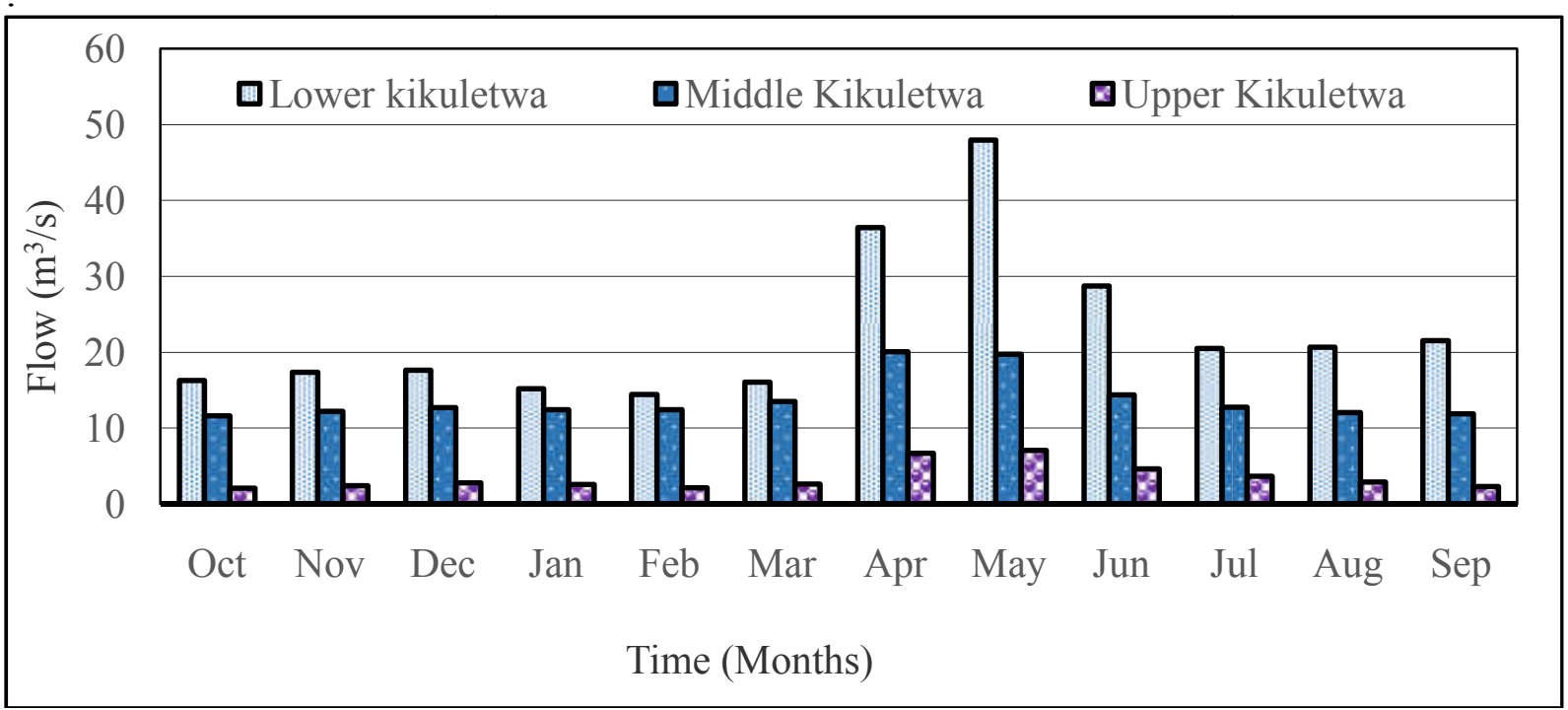

Figure 6: Streamflow Comparison for the Upper, Middle and Lower Kikuletwa

\section{Flow seasonality change}

The results of seasonality changes are presented in Figure 7. No shifting of seasons was observed. The flow peaks in the past are higher compared to the flow peaks in recent decades. Compared with the past, the longest time series at station IDD1 (outlet of the catchment) indicated a decrease in flow peaks from the 1980s except for few cases which mostly correspond to the extreme events, for example, 1978 floods, 1982 and $1997 \mathrm{El}$ Nino. 


\section{Trends of the normal (annual and seasonal) flow}

The results of trends in mean annual and seasonal flow for both periods are presented in Figures 8 and 9. Annual flow trends for the common period indicated significant decreasing trends with $\mathrm{Z}$ values of $-2.52,-2.28,-1.99$, and -3.41 for the stations IDD1, IDD54, IDD55, and IDD8A, respectively. On contrary the trends in the whole series indicated a decreasing trend also for all stations but, only two stations located above the Rundugai natural springs were the ones that indicated significantly decreasing trends. On the other hand, for seasonal trend analysis, the AMJ season indicated a significant decreasing trend with $Z$ values of -4.72 and -3.07 for both common period and whole period series, respectively at station IDD1. The FM season indicated insignificant decreasing trends with $\mathrm{Z}$ values of -1.59 at station 1DD55 while a significant decreasing trend was indicated at stations IDD1, IDD54, and IDD8A with $Z$ values of -2.1 , -2.0 , and -3.1 , respectively, for the common period. Station IDD1 located below the Rundugai natural springs indicated increasing trends in NDJ, FM, and JASO seasons for the whole series. This could be contributed by high rainfall in the past which might have recharged the groundwater aquifers which then contributed to flow during the dry season through groundwater base flow.

\section{Abrupt change on the normal (mean annual and seasonal) flow}

Mean annual flow change point analysis of the common series (Table 4) indicated a significant downward shift for stations IDD1, IDD55, and IDD8A with $t$ values of 2.88, 2.42, and 2.54 in 1998, 1998 and 1991, respectively. The insignificant downward shift was observed at station IDD54 with a $t$ value of 1.38 in 1999 . On the other hand, the whole series showed a significant downward shift (Table 5) at the station IDD55 located above the Rundugai natural springs and an insignificant downward shift at the station IDD54 located below the Rundugai natural springs. 


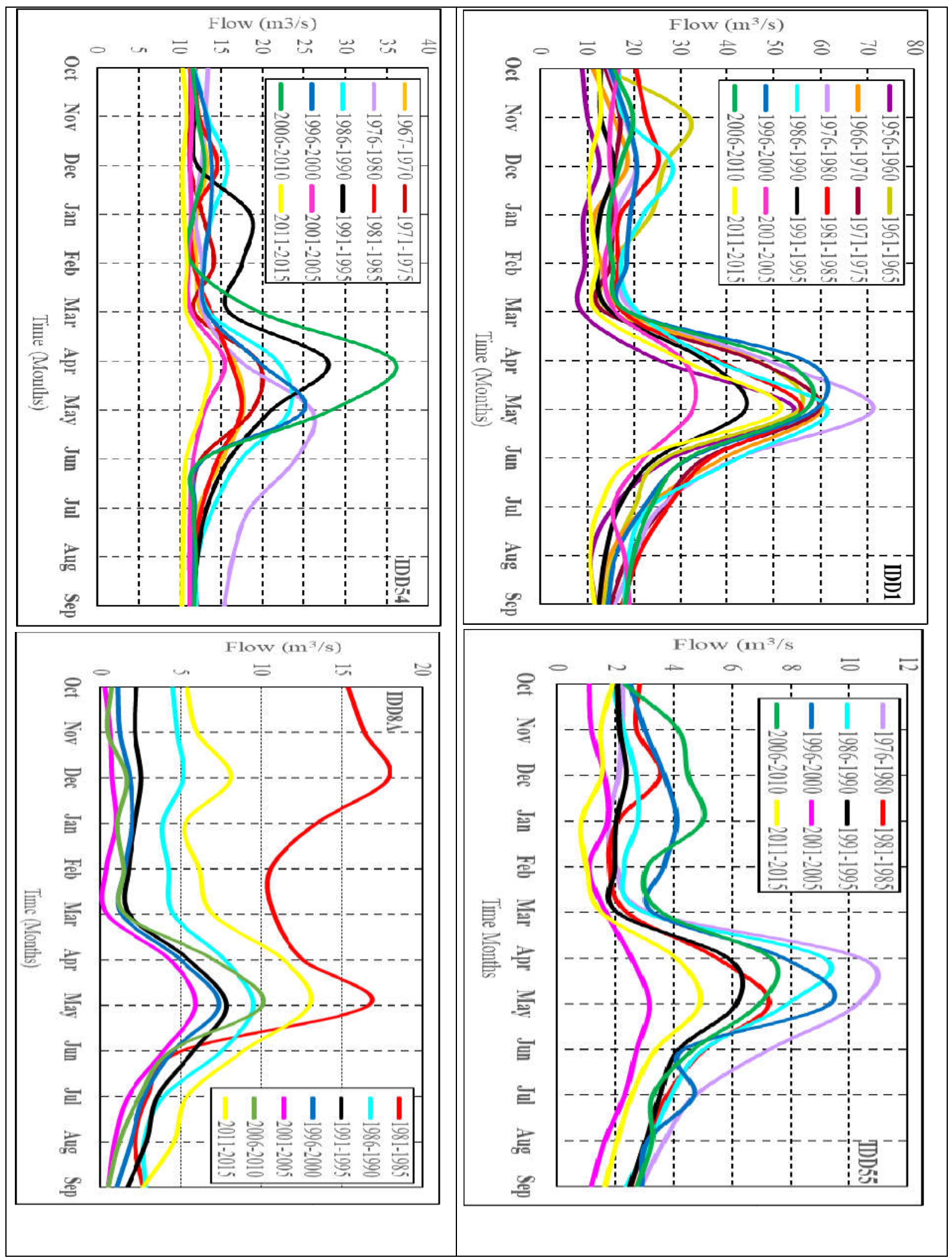

Figure 7: Changing of Flow Seasonality in Kikuletwa Catchment of Pangani Basin 
Spatial and Temporal Variation of Rainfall and Streamflow in the Kikuletwa Catchment of Upper Pangani Basin, Tanzania

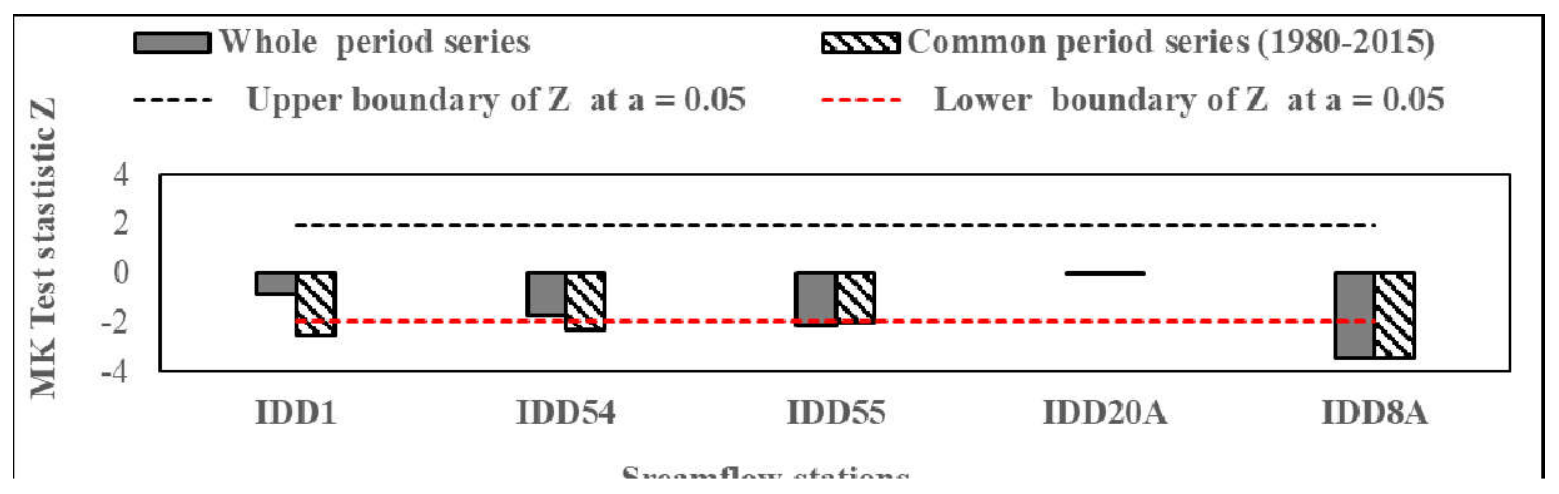

Figure 8: Mann-Kendall statistic $Z$ value for Average Annual Flow

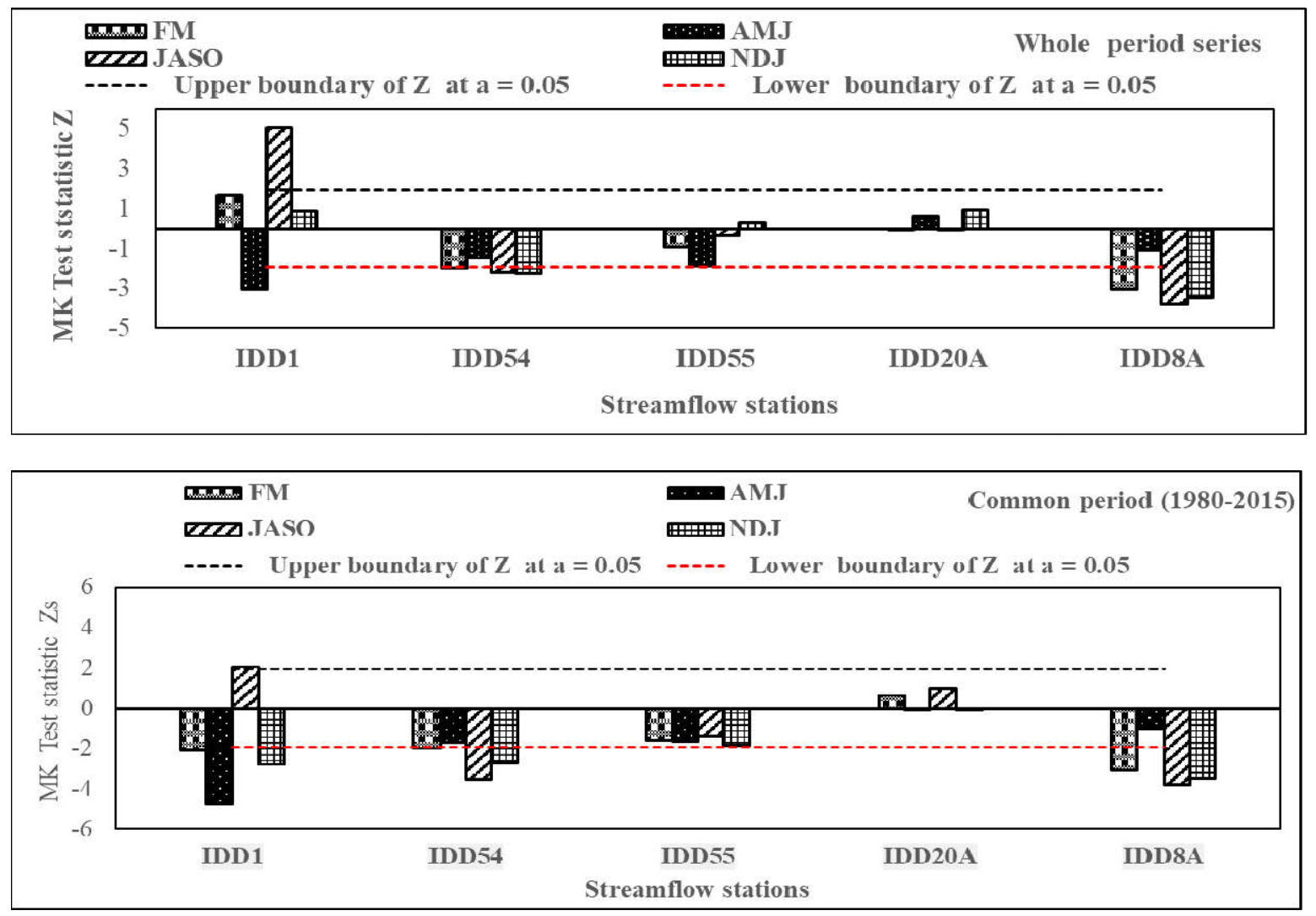

Figure 9: Mann-Kendall statistic Z Value for Seasonal Average Flow

Table 4: Abrupt change point on average annual flow from 1980-2015

\begin{tabular}{|c|c|c|c|c|c|c|}
\hline \multicolumn{5}{|c|}{ Changepoint-Pettitt test } & \multicolumn{2}{|r|}{ t-test } \\
\hline Station & Shift year & $\begin{array}{c}\text { Mean } \\
\text { regime } 1\end{array}$ & $\begin{array}{c}\text { Mean } \\
\text { regime } 2\end{array}$ & $\begin{array}{c}\text { Change } \\
(\%)\end{array}$ & t- value & Remarks \\
\hline IDD1 & 1998 & 25.97 & 20.40 & -21.45 & 2.88 & Significant \\
\hline IDD54 & 1999 & 14.55 & 12.91 & -11.27 & 1.38 & Insignificant \\
\hline IDD55 & 1998 & 3.90 & 2.60 & -33.33 & 2.42 & Significant \\
\hline IDD8A & 1991 & 7.33 & 3.66 & -50.07 & 2.54 & Significant \\
\hline
\end{tabular}


Table 5: Abrupt change point on average annual flow for the whole series

\begin{tabular}{|l|c|c|c|c|c|l|}
\hline \multicolumn{9}{|c|}{ Changepoint -Pettitt test } & \multicolumn{2}{c|}{ t-test } \\
\hline Station & Shift year & $\begin{array}{c}\text { Mean } \\
\text { regime 1 }\end{array}$ & $\begin{array}{c}\text { Mean } \\
\text { regime 2 }\end{array}$ & $\begin{array}{c}\text { Change } \\
(\%)\end{array}$ & value & Remarks \\
\hline IDD54 & 1999 & 14.43 & 12.91 & -10.53 & 1.41 & Insignificant \\
\hline IDD55 & 1998 & 4.08 & 2.60 & -36.24 & 2.69 & Significant \\
\hline
\end{tabular}

Change point analysis of mean seasonal flow in the whole series indicated a significant upward shift at station IDD1 for low (FM), dry season (JASO), and medium (NDJ) flow seasons which occurred in the 1960s and 1970s (Table 6). This could be contributed by high rainfall in the 1960s and 1970s as revealed in Figure 4. This might have recharged the groundwater aquifers that contributing to low flow. On the other hand, the general observation for the common period (Table 7) indicated a significant downward shift in 1998, 1999, 2002, and 2004. And this could be attributed to the decline of rainfall and catchment influences after the 1980s.

Table 6: Abrupt change point on average annual flow for the whole series

\begin{tabular}{|c|c|c|c|c|c|c|c|}
\hline \multicolumn{6}{|c|}{ Change point -Pettit test } & \multicolumn{2}{|c|}{ Two-Sample t-test } \\
\hline Station & Season & $\begin{array}{l}\text { Change } \\
\text { year }\end{array}$ & $\begin{array}{l}\text { Mean } \\
\text { regime 1 }\end{array}$ & $\begin{array}{l}\text { Mean regime } \\
2\end{array}$ & $\begin{array}{c}\text { Change } \\
(\%)\end{array}$ & t-value & Remarks \\
\hline \multirow[b]{4}{*}{ IDD1 } & FM & 1961 & 9.25 & 16.32 & 76.43 & -4.16 & $\mathrm{~S}$ \\
\hline & AMJ & 1999 & 44.49 & 19.47 & -56.24 & 5.60 & $\mathrm{~S}$ \\
\hline & JASO & 1970 & 14.27 & 22.56 & 58.09 & -3.20 & $\mathrm{~S}$ \\
\hline & NDJ & 1970 & 9.87 & 17.96 & 81.97 & -3.85 & $\mathrm{~S}$ \\
\hline \multirow[b]{3}{*}{$1 D D 54$} & FM & 1999 & 13.21 & 12.59 & -4.69 & 0.57 & NS \\
\hline & JASO & 1999 & 12.69 & 11.19 & -11.82 & 1.99 & NS \\
\hline & NDJ & 1998 & 13.12 & 11.54 & -12.04 & 2.59 & $\mathrm{~S}$ \\
\hline \multirow[b]{4}{*}{$1 D D 55$} & FM & 1998 & 2.69 & 1.99 & -26.15 & 1.45 & NS \\
\hline & AMJ & 1998 & 7.47 & 4.18 & -44.07 & 2.7 & $\mathrm{~S}$ \\
\hline & JASO & 1998 & 3.23 & 2.04 & -36.61 & 3.19 & $\mathrm{~S}$ \\
\hline & NDJ & 1998 & 2.76 & 2.28 & -17.36 & 0.88 & NS \\
\hline \multirow[b]{3}{*}{ 1DD8A } & FM & 1987 & 9.46 & 2.39 & -74.74 & 4.34 & $\mathrm{~S}$ \\
\hline & JASO & 1995 & 4.14 & 2.50 & -39.64 & 1.59 & NS \\
\hline & NDJ & 1995 & 7.55 & 2.49 & -67.02 & 2.55 & $\mathrm{~S}$ \\
\hline
\end{tabular}

*S indicates significant and *NS not significant

Trends and change-point analysis in extreme high flow

The results of trends analysis for high flow indices are presented in Tables 8 for both series whereby significant trends are presented in bold and shaded. The whole series indicated the increasing trends for Annual_QMax for the stations located below the Rundugai natural springs and decreasing trends for the station located above the springs. Q5 April and May_Qmax. indicated decreasing trends. On the other hand, during 1980-2015, almost all indices indicated a decreasing trend. The change-point analysis of high flow indices for the whole series is presented in Tables 9. It shows a 
significant downward shift for station IDD1 in 1998 and 1999 with $t$ values of 3.59 and 6.0 on April and May__max, respectively. Q5 and annual_Qmax at station IDD55 indicated a significant downward shift. During 1980-2015, the significant upward shift (Table 10) was observed in annual and May_Qmax at the stations IDD55 and IDD8A in the 2000s.

Generally, the trend analysis of low flow indices during 1980-2015 indicated the significant decreasing trends for all indices except Annual_Qmin. which showed an insignificant increasing trend at station IDD1. For the whole series, general observations indicated an insignificant decreasing trend for all stations except station IDD1 which indicated a significant increasing trend. On the other hand, change-point analysis during 1980-2015 shows a significant downward shift (Table 12) for all indices in 1986, 1991, 1998, 1999, 2000, and 2002 except for Annual_Qmin, Feb_QMin and March_QMin indices which did not indicate any shift.

\section{Trends and change-point analysis in extreme low flow}

The results of trends analysis for high flow indices are presented in Tables 11 for both series. For the whole series, a significant upward shift (Table 13) was observed only at station IDD1 located at the outlet of the catchment in the early 1970 s while other stations indicated an insignificant downward shift in 1998, 1999, and 2000.

Table 7: Abrupt change point on average annual flow from 1980-2015

\begin{tabular}{|c|c|c|c|c|c|c|c|}
\hline \multicolumn{6}{|c|}{ Change point -Pettit test } & \multicolumn{2}{|c|}{ Two -Sample t-test } \\
\hline Station & Season & Change year & Mean regime 1 & Mean regime 2 & Change (\%) & t-value & Remarks \\
\hline \multirow[b]{3}{*}{ IDD1 } & AMJ & 2002 & 43.90 & 16.43 & -62.57 & 6.6 & $\mathrm{~S}$ \\
\hline & JASO & 2004 & 17.60 & 34.43 & 95.60 & -6.64 & $\mathrm{~S}$ \\
\hline & NDJ & 1987 & 21.22 & 15.63 & -26.34 & 2.70 & $\mathrm{~S}$ \\
\hline \multirow[b]{3}{*}{ 1DD54 } & FM & 1999 & 13.55 & 12.59 & -7.08 & 0.67 & NS \\
\hline & JASO & 1999 & 12.29 & 11.19 & -8.95 & 3.67 & $\mathrm{~S}$ \\
\hline & NDJ & 1998 & 13.79 & 11.53 & -16.39 & 3.10 & $\mathrm{~S}$ \\
\hline \multirow[b]{3}{*}{ IDD55 } & AMJ & 1998 & 6.81 & 4.18 & -38.62 & 2.59 & $\mathrm{~S}$ \\
\hline & JASO & 1998 & 3.14 & 2.04 & -35.03 & 3.04 & $\mathrm{~S}$ \\
\hline & NDJ & 1998 & 2.91 & 2.28 & -21.65 & 0.98 & $S$ \\
\hline \multirow[b]{3}{*}{ 1DD8A } & FM & 1987 & 9.46 & 2.39 & -74.74 & 4.34 & $S$ \\
\hline & JASO & 1995 & 4.14 & 2.50 & -39.64 & 1.59 & $\mathrm{NS}$ \\
\hline & NDJ & 1995 & 7.55 & 2.49 & -67.02 & 2.55 & $\mathrm{~S}$ \\
\hline
\end{tabular}

Table 8: Mann-Kendall statistic $Z$ value for high flow extremes indices

\begin{tabular}{|c|c|c|c|c|c|c|c|c|c|}
\hline \multirow{2}{*}{ S/N } & \multirow{2}{*}{ Station } & \multicolumn{3}{|c|}{ MK test -Z values for whole series } & \multicolumn{3}{c|}{ MK test -Z values from 1980-2015 } \\
\cline { 3 - 9 } & & $\begin{array}{c}\text { Annual__ } \\
\text { Qmax. }\end{array}$ & $\mathbf{Q 5}$ & $\begin{array}{c}\text { April_Q } \\
\text { max. }\end{array}$ & $\begin{array}{c}\text { May_Q } \\
\text { max }\end{array}$ & $\begin{array}{c}\text { Annual_ } \\
\text { Qmax. }\end{array}$ & Q5 & $\begin{array}{c}\text { April_ } \\
\text { Qmax. }\end{array}$ & May_Qmax \\
\hline 1 & IDD1 & 1.01 & -1.32 & -2.64 & -5.45 & 1.67 & -0.98 & -3.38 & -4.45 \\
\hline 2 & IDD54 & 0.02 & -1.63 & 0.07 & -1.82 & 0.56 & -1.80 & 0.43 & -1.48 \\
\hline 3 & IDD55 & -2.39 & -2.50 & -2.40 & -1.95 & 1.65 & -2.19 & -0.15 & 1.95 \\
\hline 4 & IDD20A & -0.32 & -0.21 & -0.67 & 0.31 & -0.32 & -0.21 & -0.67 & 0.31 \\
\hline 5 & IDD8A & 1.65 & -1.89 & -0.15 & 1.95 & 1.65 & -1.89 & -0.15 & 1.95 \\
\hline
\end{tabular}


Table 9: Abrupt change point on high flow indices for the whole series

\begin{tabular}{|c|c|c|c|c|c|c|c|c|}
\hline \multicolumn{7}{|c|}{ Change point -Pettit test } & \multicolumn{2}{|c|}{ t-test } \\
\hline Statio & Flow indices & $\begin{array}{c}\text { Change } \\
\text { year }\end{array}$ & $\begin{array}{c}\text { Mean } \\
\text { regime } 1\end{array}$ & $\begin{array}{c}\text { Mean } \\
\text { regime } 2\end{array}$ & $\begin{array}{c}\begin{array}{c}\text { Change } \\
(\%)\end{array} \\
\end{array}$ & $\begin{array}{l}\text { Change } \\
\text { direction }\end{array}$ & t-value & Remarks \\
\hline \multirow{2}{*}{$\begin{array}{c}\text { IDD1 } \\
(1952-2015)\end{array}$} & April_Qmax & 1999 & 121.52 & 43.01 & -64.61 & Downward & 3.59 & $\mathrm{~S}$ \\
\hline & May_Qmax & 1998 & 117.17 & 36.77 & -68.62 & Downward & 6.00 & $\mathrm{~S}$ \\
\hline \multirow{2}{*}{$\begin{array}{c}\text { IDD55 } \\
(1976-2015) \\
\end{array}$} & Q5 & 1998 & 10.062 & 5.56 & -44.74 & Downward & 3.67 & $\mathrm{~S}$ \\
\hline & Annual_Qmax & 1998 & 26.312 & 13.035 & -50.46 & Downward & 2.97 & $\mathrm{~S}$ \\
\hline
\end{tabular}

Table 10: Abrupt change point on high flow from 1980-2015

\begin{tabular}{|c|c|c|c|c|c|c|c|c|}
\hline \multicolumn{7}{|c|}{ Change point -Pettit test } & \multicolumn{2}{|c|}{ Two -Sample t-test } \\
\hline $\begin{array}{l}\text { Station } \\
\text { /Time }\end{array}$ & Flow indices & $\begin{array}{c}\text { Change } \\
\text { year }\end{array}$ & $\begin{array}{c}\text { Mean } \\
\text { regime } 1\end{array}$ & $\begin{array}{c}\text { Mean } \\
\text { regime 2 }\end{array}$ & $\begin{array}{c}\text { Change } \\
(\%)\end{array}$ & $\begin{array}{l}\text { Change } \\
\text { direction }\end{array}$ & t-value & Remarks \\
\hline \multirow[t]{2}{*}{ IDD1 } & April_Qmax & 2004 & 113.67 & 26.35 & -76.82 & Downward & 4.35 & $\mathrm{~S}$ \\
\hline & May_Qmax & 2003 & 96.33 & 25.44 & -73.59 & Downward & 5.49 & $\mathrm{~S}$ \\
\hline \multirow[b]{3}{*}{ IDD55 } & Q5 & 1998 & 9.25 & 5.56 & -39.89 & Downward & 2.32 & $\mathrm{~S}$ \\
\hline & Annual Qmax & 2002 & 15.24 & 24.41 & 60.17 & Upward & -3.61 & $\mathrm{~S}$ \\
\hline & May_Qmax & 2004 & 12.45 & 23.26 & 86.83 & Upward & -2.06 & $\mathrm{~S}$ \\
\hline \multirow[t]{2}{*}{ IDD8A } & Annual_Qmax & 2002 & 15.23 & 24.46 & 60.60 & Upward & -3.28 & $\mathrm{~S}$ \\
\hline & May_Q_max & 2004 & 12.45 & 23.26 & 86.83 & Upward & -3.65 & $\mathrm{~S}$ \\
\hline
\end{tabular}

Table 11: Mann-Kendall statistic $Z$ value for low flow extremes indices

\begin{tabular}{|c|l|l|c|c|c|c|c|c|c|c|c|}
\hline \multirow{2}{*}{ S/N } & Station & \multicolumn{3}{|c|}{ MK test -Z values for whole series } & \multicolumn{3}{c|}{ MK test -Z values from 1980-2015 } \\
\cline { 3 - 14 } & & $\begin{array}{c}\text { Annual_- } \\
\text { Qmin. }\end{array}$ & $\mathbf{Q 7 0}$ & $\mathbf{Q 9 5}$ & $\begin{array}{c}\text { Feb__ } \\
\text { Qmin }\end{array}$ & $\begin{array}{c}\text { March } \\
\text { Qmin }\end{array}$ & $\begin{array}{c}\text { Annual_- } \\
\text { Qmax. }\end{array}$ & Q70 & Q95 & $\begin{array}{c}\text { Feb_- } \\
\text { Qmin }\end{array}$ & $\begin{array}{c}\text { March } \\
\text { Qmin }\end{array}$ \\
\hline 1 & IDD1 & 4.35 & 2.43 & 2.62 & 2.68 & 2.44 & 0.32 & -2.92 & -2.21 & -1.05 & -1.91 \\
\hline 2 & IDD54 & 0.19 & -1.53 & -0.48 & -1.46 & -1.78 & -3.78 & -2.80 & -3.42 & -3.52 & -3.52 \\
\hline 3 & IDD55 & -1.33 & -1.14 & -0.65 & -1.10 & -0.82 & -3.75 & -1.46 & -1.20 & -3.93 & -3.25 \\
\hline 4 & IDD20A & -0.42 & 0.86 & 1.00 & 0.45 & 0.86 & -0.42 & 0.86 & 1.00 & 0.45 & 0.86 \\
\hline 5 & IDD8A & -2.77 & -3.20 & -3.59 & -3.93 & -3.25 & -2.77 & -3.20 & -3.59 & -3.93 & -3.25 \\
\hline
\end{tabular}

Table 12: Abrupt change point on low flow from 1980-2015

\begin{tabular}{|c|c|c|c|c|c|c|c|c|}
\hline \multicolumn{7}{|c|}{ Change point -Pettit test } & \multicolumn{2}{|c|}{ Two -Sample t-test } \\
\hline $\begin{array}{c}\text { Station/ } \\
\text { Time }\end{array}$ & Flow indices & $\begin{array}{c}\text { Change } \\
\text { year }\end{array}$ & $\begin{array}{c}\text { Mean } \\
\text { regime 1 }\end{array}$ & $\begin{array}{c}\text { Mean } \\
\text { regime 2 }\end{array}$ & $\begin{array}{c}\text { Change } \\
(\%)\end{array}$ & $\begin{array}{l}\text { Change } \\
\text { direction }\end{array}$ & t value & Remarks \\
\hline \multirow[b]{2}{*}{ IDD1 } & Q70 & 1986 & 17.23 & 12.89 & -25.19 & Downward & 4.59 & $\mathrm{~S}$ \\
\hline & Q95 & 1986 & 15.10 & 11.35 & -24.83 & Downward & 3.72 & $\mathrm{~S}$ \\
\hline \multirow{5}{*}{ IDD54 } & Annual_Qmin & 1998 & 11.27 & 10.45 & -7.28 & Downward & 4.27 & $\mathrm{~S}$ \\
\hline & Q70 & 1999 & 12.03 & 11.15 & -7.32 & Downward & 3.91 & $\mathrm{~S}$ \\
\hline & Q95 & 2002 & 11.13 & 10.53 & -5.39 & Downward & 3.69 & $\mathrm{~S}$ \\
\hline & Feb_Qmin & 1998 & 12.81 & 10.72 & -16.32 & Downward & 2.68 & $\mathrm{~S}$ \\
\hline & March_Qmin & 2000 & 12.29 & 10.74 & -12.61 & Downward & 2.79 & $\mathrm{~S}$ \\
\hline \multirow{5}{*}{ IDD55 } & Annual_Qmin & 1998 & 1.38 & 0.78 & -43.48 & Downward & 2.74 & $\mathrm{~S}$ \\
\hline & Q70 & 1998 & 2.37 & 1.54 & -35.02 & Downward & 2.98 & $\mathrm{~S}$ \\
\hline & Q95 & 1998 & 1.61 & 1.05 & -34.78 & Downward & 2.53 & $\mathrm{~S}$ \\
\hline & Feb_Qmin & 1991 & 6.87 & 1.73 & -74.82 & Downward & 3.94 & $\mathrm{~S}$ \\
\hline & March_Qmin & 1990 & 7.62 & 1.78 & -76.64 & Downward & 2.53 & $\mathrm{~S}$ \\
\hline \multirow{5}{*}{ IDD8A } & Annual_Qmin & 1998 & 0.89 & 0.21 & -76.40 & Downward & 3.33 & $\mathrm{~S}$ \\
\hline & Q70 & 1995 & 3.52 & 1.86 & -47.16 & Downward & 1.59 & NS \\
\hline & Q95 & 1998 & 1.56 & 0.12 & -92.31 & Downward & 6.45 & $\mathrm{~S}$ \\
\hline & Feb_Qmin & 1991 & 6.87 & 1.73 & -74.82 & Downward & 3.94 & $\mathrm{~S}$ \\
\hline & March_Qmin & 1990 & 7.62 & 2.18 & -71.39 & Downward & 3.61 & $\mathrm{~S}$ \\
\hline
\end{tabular}


Table 13: Abrupt change point on low flow for the whole series

\begin{tabular}{|c|c|c|c|c|c|c|c|}
\hline \multicolumn{7}{|c|}{ Change point -Pettit test } & \multicolumn{2}{c|}{ t-test } \\
\hline Flow indices & $\begin{array}{c}\text { Change } \\
\text { year }\end{array}$ & $\begin{array}{c}\text { Mean } \\
\text { regime 1 }\end{array}$ & $\begin{array}{c}\text { Mean } \\
\text { regime 2 }\end{array}$ & $\begin{array}{c}\text { Change } \\
\mathbf{( \% )}\end{array}$ & $\begin{array}{c}\text { Change } \\
\text { direction }\end{array}$ & t value & Remarks \\
\hline Annual_Qmin & 1973 & 8.48 & 11.46 & 35.14 & Upward & -4.57 & $\mathrm{~S}$ \\
\hline Q70 & 1971 & 10.53 & 14.24 & 35.23 & Upward & -4.31 & $\mathrm{~S}$ \\
\hline Q95 & 1972 & 9.18 & 12.95 & 41.07 & Upward & -4.31 & $\mathrm{~S}$ \\
\hline Feb_Qmin & 1971 & 9.82 & 13.36 & 36.05 & Upward & -3.32 & $\mathrm{~S}$ \\
\hline March_Qmin & 1974 & 10.24 & 13.45 & 31.35 & Upward & -3.51 & $\mathrm{~S}$ \\
\hline Annual_Qmin & 1976 & 9.22 & 10.89 & 18.11 & Upward & -5.20 & $\mathrm{~S}$ \\
\hline Q70 & 1999 & 11.85 & 11.15 & -5.91 & Downward & 3.04 & $\mathrm{~S}$ \\
\hline Feb_Qmin & 1998 & 11.98 & 10.72 & -10.52 & Downward & 2.02 & $\mathrm{~S}$ \\
\hline March_Qmin & 2000 & 11.66 & 10.75 & -7.80 & Downward & 1.83 & $\mathrm{NS}$ \\
\hline Annual_Qmin & 1998 & 1.32 & 0.89 & -32.07 & Downward & 1.98 & $\mathrm{NS}$ \\
\hline
\end{tabular}

\section{DISCUSSION}

Rainfall variations analysis indicated similar results for the whole series and common period. The general observations for most of the stations indicated decreasing trends in rainfall amounts in the catchment though not significant for most stations. Significant decreasing trends and downward shifts were observed only at the two stations located on the upstream of the catchment. These results of decreasing in rainfall in Kikuletwa and Pangani River basin as a whole, are similar to the findings from previous studies (e.g. Mkhandi and Ngana, 1999, Hemp, 2005; IPCC, 2007; Munishi and Sawere, 2014; Lalika et al., 2014; Otte et al., 2017).

Streamflow variations analysis, on the other hand, showed differences for the two periods of analysis for station IDD1 located at the outlet of the catchment and below the Rundugai natural springs. For the whole time series (which included the 1950s to 2015 years) average annual flow trends indicated an insignificant decreasing trend at station IDD1 while for common period same station IDD1 indicated a significant decreasing trend. Low flow (FM and JASO) and medium (NDJ) flow seasons in the same station for the whole series indicated increasing trends. This could be contributed by high rainfall in the past which might have recharged the groundwater aquifers which then contributed to flow during the dry season through groundwater base flow. In contrast, trend analysis during 1980-2015 (common period) for the FM season indicated a decreasing trend which was significant in four stations. The decrease in the flow revealed in the study area is supported by other previous studies (e.g. Valimba and Mkhandi, 2005; Lalika et al., 2014; Munishi and Sawere, 2014). Munishi et al. (2009) recommended that an analysis should be done to examine the trend for low flow months in tributaries of Kikuletwa catchment located above the Rundugai natural springs. The results of trends to the tributaries located above the Rundugai springs analyzed in this study indicated decreasing trends for low flow season.

To relate the flow variability during 19802015 with the decreasing trend in rainfall indicates the presence of other factors of streamflow changes. This can be evidenced from the trend analysis of the annual rainfall amounts which showed significant decreasing trends for only two stations located at the upstream of the catchment, but trends of the average annual flow indicated a significant decrease for most of the stations during 1980-2015. Also, rainfall amounts indicated decreasing trends but the annual maximum flow indicated increasing trends. Thus, not only the rainfall decrease in the catchment has caused flow 
variations but also the presence of other catchment influences. With increased population, human activities became much intense leading to environmental degradation with negative effects on water resources (Shishira, 2002; Shaghude, 2006). The study by de Wit and Stankiewicz (2006) showed further that, land-use change and environmental degradation could be other factors that would decrease streamflow in Pangani Basin. Also, Hemp (2009) revealed that over the past 70 years, the forest in the upper areas of Mount Kilimanjaro has decreased to about one-third of its origin, and the cause was climate-driven fire and land clearing which resulted to the reduction in cloud forests and water yield. Not only that but, intense irrigated agriculture could also be the source of a decreased flow in the dry season.

\section{CONCLUSIONS}

The study revealed the spatial and temporal variation of rainfall and streamflow in the study area. The whole time series analysis of annual rainfall and streamflow amounts revealed a decrease in rainfall and streamflow amounts for almost all stations though a significant decrease was only observed at two stations located on the upstream (for rainfall) and two stations located above the Rundugai natural springs (for streamflow). During $1980-2015$ (common period) annual rainfall trend analysis showed significant decreasing trends for only two stations located at the upstream of the catchment and trends of the average annual flow indicated a significant decrease for most of the stations. There is an existence of other catchment influences to the streamflow changes other than rainfall during 19802015. The study provided very useful information that decides the necessity for separating the climate and human influences to the streamflow changes to find the most influencing factor.

\section{ACKNOWLEDGMENT}

African Development Bank (AfDB) through the Ministry of Education of Tanzania is thanked for the financial support extended to the first author.

\section{REFERENCES}

Camberlin P. and Philippon N. (2002). The East African March-May rainy season: Associated atmospheric dynamics and predictability over the 1968-97 period. J. Climate, 15: 1002-1019. DOI: 10.1175/1520-0442(2002)015, $\quad 1002$ : TEAMMR.2.0.CO;2.

Chan R.Y., Vuille M., Hardy D.R. and Bradley R.S. (2008). Intraseasonal precipitation variability on Kilimanjaro and the East African region and its relationship to the large-scale circulation. Appl. Climatol., 93: 149165. DOI: $10.1007 /$ s00704-007-03389.

de Wit M. and Stankiewicz J. (2006). Changes in Surface Water Supply across Africa with Predicted Climate Change. Science 311: 1917- 192. DOI: $10.1126 /$ science. 1119929

Gray D.M. (1970). Handbook on the principles of hydrology. Secretariat, Can. Natl. Comm. Int. Hydrol. Decade, Natl. Res. Counc. Can., Ottawa, Ont.

Grossmann M. (2008). Kilimanjaro Aquifer. In: Conceptualizing Cooperation for Africa's Transboundary Aquifer Systems, edited by Scheumann, W. and HerrfahrdtPahle, E; DIE Studies Nr 32, German Development Institute, 87-125, Bonn.

Hemp A. (2005). Climate change-driven forest fires marginalize the ice cap wasting on Mt. Kilimanjaro. Glob. Change Biol. 11: 1013-1023. https://doi.org/10.1111/j.13652486.2005.00968.x

Hemp A. (2009). Climate change and its impact on the forests of Kilimanjaro. African Journal of Ecology, 47(Suppl. 
1): $\quad 3-10$. DOI: $10.1111 / \mathrm{j} .1365-$ 2028.2008.01043.x

IPCC (2007). World Meteorological Organization (WMO) Guide to climate Change Practice. World Meteorology. Organization general Publisher, New York.

IPCC (2014). Climate Change 2014: Synthesis Report. Contribution of Working Groups I, II, and III to the Fifth Assessment Report of the Intergovernmental Panel on Climate Change [Core Writing Team, R.K. Pachauri, and L.A. Meyer (eds.)]. IPCC, Geneva, Switzerland, $151 \mathrm{p}$.

Kendall M.G. (1975). Rank Correlation Methods. 4th Edition, Charles Griffin, London. 202p.

Kundzewicz Z.W., Robson A.J. (2004). Change detection in hydrological records- A review of the methodology. Hydrological Sciences Journal, 49(1): 7-19. DOI: $10.1623 /$ hysj.49.1.7.53993

Lalika M.C.S., Meire P., Ngaga Y. M., and Changa' L. (2014). Understanding Watershed Dynamics and Impacts of Climate Change and Variability in the Pangani River Basin, Tanzania Hydrological Sciences Journal, 59(5): 1095-1108. DOI:10.1080/ 02626667.2013 .819433$.

Langat P.K., Kumar L. and Koech R. (2017). Temporal Variability and Trends of Rainfall and Streamflow in Tana River Basin, Kenya. Sustainability 2017, 9, 1963; DOI:10.3390/su9111963.

Mann H.B. (1945). Non-parametric tests against trend. Econometrica 13: 245$259 . \quad$ https://doi.org/00129682(194507)13:3<245:NTAT $>2.0 . \mathrm{CO}$ ;2-U

Mkhandi S.H. and Ngana J.O. (1999). Trend analysis and spatial variability of annual rainfall in the Pangani River basin. In Ngana (Ed.) (1999): Water management in Pangani river basin, Challenges, and opportunities, Dar Es Salaam University Press, $11-20$.
Munishi K.T., Hermegast A.M. and Mbilinyi B.P. (2009). The Impacts of Changes in Vegetation Cover on Dry Season Flow in The Kikuletwa River Northern Tanzania. African Journal of Ecology, https://doi.org/10.1111/j.13652028.2008.01083.x

Mutai C.C. and Ward N.M. (2000). East African rainfall and the tropical circulation/convection on intraseasonal to interannual timescales, J. Climate, 13: 3915-3939. https://doi.org/10.1175/15200442(2000)013<3915:EARATT $>2.0 . C O ; 2$

Nyenzi B.S., Kavishe M.M., Nassib I.R. and Tilya F.F. (1999). Analysis of meteorological droughts in Tanzania, Proc. of an Interdisciplinary International Conference on Integrated Drought Management, September 2022, Pretoria, South Africa.

Otte I. and Detsch F. (2017). Multidecadal Trends and Interannual Variability of Rainfall as Observed from Five Lowland Stations at Mt. Kilimanjaro, Tanzania. Journal of hydrometeorology. DOI: 10.1175/JHM-D-16-0062.1.

PBWO/IUCN (2008). Basin Delineation Report. Pangani Basin Water Board, Moshi and IUCN Eastern and Southern Africa Regional Programme, Nairobi. $57 \mathrm{p}$.

Pettitt A.N. (1979). A Non-Parametric Approach to the Change-Point Problem. Journal of the Royal Statistical Society. Series C (Applied Statistics), 28: 126135. https://doi.org/10.2307/2346729

Røhr P.C. and Killingtveit A. (2002). Study of two catchments on the hillside of Mt Kilimanjaro. Water Resources Management: The Case of Pangani River Basin. Issues and Approaches (Ed. J.O. Ngana) Dar es Salaam University Press, Tanzania.

Shaghude Y.W. (2006). Review of water resource exploitation and land-use pressure in Pangani River Basin, Tanzania. Western Indian Ocean Marine Science Association Journal 
(5)2:

195-207.

DOI: $10.4314 /$ wiojms.v5i2.28510

Shishira E.K. (2002). Land-use changes and sustainability of water resources utilization in the Pangani river basin downstream of the Nyumba ya Mungu dam. In: Water Resources Management. The Case of Pangani River Basin, Issues, and Approaches (Ed. J.O. Ngana) Dar es Salaam University Press, Dar es Salaam.

Valimba P. (2004). Rainfall variability in southern Africa, its influences on streamflow variations, and its relationships with climatic variations. Ph.D. Thesis, Rhodes University.

Valimba P. (2008). Temporal Flow Variations: A Challenge for Surface Water Management in Tanzania, World Water Congress, Montpellier, France, 1-4 September 2008.

Valimba P. and Mkhandi S.H. (2005). Changing Flows in Southern Africa and Its Relationships to Rainfall Variations. Climatic and anthropogenic impacts on the variability of water resources.
International Hydrological Programme, Technical Documents in Hydrology No. 80, UNICEF, 22-24 November.

$\mathrm{Xu}$ Z.X., Liu Z.F., Fu G.B. and Chen Y.N. (2010). Trends of major hydroclimatic variables in the Tarim River basin during the past 50 years, Journal of Arid Environments, 74: 256-267. doi:10.1016/j.jaridenv.2009.08.014

Zhang A., Zheng C., Wang S. and Yao Y. (2015). Analysis of streamflow variations in the Heihe River Basin, northwest China: Trends, abrupt changes, driving factors, and ecological influences. Journal of Hydrology: Regional Studies 3: 106-124. https://doi.org/10.1016/j.ejrh.2014.10.005

Zheng H., Zhang L., Zhu R., Liu C., Sato Y. and Fukushima Y. (2009). Responses of streamflow to climate and land surface change in the headwaters of the Yellow River Basin, Water Resources Research, 45, W00A19.http://dx.doi.org/10.1029/200 7WR006665. 